\title{
Main themes, barriers, and solutions to palliative and end-of-life care in the English-speaking Caribbean: a scoping review
}

\author{
Nicholas Jennings, ${ }^{1}$ Kenneth Chambaere, ${ }^{1}$ Cheryl C. Macpherson, ${ }^{2}$ Luc Deliens, ${ }^{1}$ \\ and Joachim Cohen ${ }^{1}$
}

Suggested citation

Jennings N, Chambaere K, Macpherson CC, Deliens L, Cohen J. Main themes, barriers, and solutions to palliative and end-of-life care in the English-speaking Caribbean: a scoping review. Rev Panam Salud Publica. 2018;42:e15. https://doi.org/10.26633/RPSP.2018.15

ABSTRACT

Objectives. To identify common themes documented in the literature on palliative and endof-life care in English-speaking Caribbean small island developing states (SIDS), and to describe barriers, improvement strategies, and suggested ways forward.

Methods. In 2015, we conducted a systematic scoping review of relevant literature identified through the MEDLINE and Web of Science databases. We supplemented that with searches of other electronic and hard-copy sources to map key concepts and summarize themes.

Results. Primary data and other literature from and about English-speaking Caribbean nations are relatively scarce. The available literature offers an overview of the existing situation in the region and explores why palliative and end-of-life care is limited there. This review identified barriers in five main areas recurring across this literature: i) culture and attitudes of health care providers, patients, and those close to them towards terminal illness and death; ii) opioid availability and use; iii) limited development of palliative care services; iv) unmet palliative care needs; and $v$ ) limited research on palliative or end-of-life care.

Conclusions. Our analysis helps to document the need for palliative and end-of-life care in Caribbean SIDS and highlights suggestions for moving forward with related practice, policy, and research.

Keywords Palliative care; terminal care; West Indies; Caribbean Region.
World Health Organization (WHO) data suggest that annually 20 million people worldwide, of whom $69 \%$ are adults over the age of 60 , require and benefit from palliative care (1). Palliative care is defined as an approach that improves the quality of life of patients and their families who are facing problems associated

\footnotetext{
End-of-Life Care Research Group, Vrije Universiteit Brussel (VUB) and Ghent University, Brussels, Belgium. Send correspondence to Nicholas Jennings, nicholas.jennings@vub.be
}

with life-threatening illness (2). The Pan American Health Organization (PAHO) predicts that by 2020 there will be 100 million people over the age of 60 in Latin America and the Caribbean (3), a growing number of whom will die from chronic and life-threatening conditions associated with prolonged periods of illness (4).

Bioethics Department, St. George's University School of Medicine and Windward Islands Research and Education Foundation, St. George's, Grenada.
In the English-speaking Caribbean, little attention is given to palliative and endof-life care. Further, despite an aging population likely to require palliative care, many of these countries do not consider palliative care a public health need, nor is it integrated into their health systems (5). Although WHO recognizes the delivery of palliative care as a major public health challenge in these countries (6), there is little empirical information on the provision of and access to palliative care $(7,8)$. 
A recent article by Maharaj and Harding (8) that focused on palliative care, needs, models, and interventions of care in the Caribbean contributed significantly to understanding the nature of palliative care in the region. Their review highlighted the need for palliative care services, which are driven by demand from an aging population and increasing morbidity from cancer and HIV/AIDS; for health care policy, staff training, and education; and for access to analgesia. However, the study included only peer-reviewed papers.

Given the scarcity of information on palliative and end-of-life care in the Caribbean, a broader exercise, such as a systematic scoping review, could map a wide range of literature, envisage gaps and innovative approaches, and provide valuable additional information (9). Moreover, the Maharaj and Harding review (8) focused on the entire Caribbean region, and not specifically on the English-speaking Caribbean. The Englishspeaking Caribbean is comprised of 12 former British colonies that have ethnically diverse populations, that are connected culturally, and that share similar political and educational structures and socioeconomic links $(10,11)$. In addition, the 12 all have health structures based on a British colonial model, consisting of a centralized ministry of health and peripheral health facilities (12). Categorized as small island developing states (SIDS), these countries are a distinct group of developing nations facing specific social, economic, and environmental vulnerabilities related to size, geographically disparate populations, and limited health work forces (13). The Caribbean Public Health Agency (CARPHA) is the single common regional public health authority for the English-speaking Caribbean (14).

The objectives for our study were to comprehensively review literature on English-speaking Caribbean SIDS to identify the common themes documented in the literature on palliative and end-of-life care in those countries, and to describe what the barriers, improvement strategies, and suggested ways forward are.

\section{MATERIALS AND METHODS}

We chose a systematic scoping review because we wanted to broadly explore the subject of palliative and end-of-life care. Scoping involves the synthesis and analysis of a wide range of research and nonresearch material to provide greater conceptual clarity about a specific topic or field of evidence. In this way, scoping considers the breadth rather than the depth of evidence (15). This methodology is considered appropriate to gain information on a broad topic and rapidly map key concepts underpinning a research area, as well as the main sources and types of evidence available. It can be undertaken as a series of stand-alone projects, especially where an area is complex or has not been previously comprehensively reviewed (16).

\section{Data collection}

Our searches of the MEDLINE and Web of Science electronic databases incorporated broad search terms commonly used when searching for palliative care and conceptually related terminology. Medical Subject Headings $(\mathrm{MeSH})$ words were used for MEDLINE (17), with this search string: ("Palliative Care"[MeSH]) OR "Terminal

TABLE 1. Definition of terms and the inclusion and exclusion criteria for publications used for the systematic scoping review of palliative and end-of-life care in the English-speaking Caribbean, 2015

\begin{tabular}{|c|c|}
\hline Category & Description \\
\hline Definition of terms & $\begin{array}{l}\text { "Palliative care" and "end-of-life care" are often used interchangeably, and we found } \\
\text { publications that used the term "palliative care" that were not relevant to our study. } \\
\text { Therefore, to standardize the decision for inclusion and exclusion of publications, the } \\
\text { publications we selected had to fit the following definition of terms: } \\
\text { Palliative and hospice care, according to the WHO (2), are specific types of } \\
\text { end-of-life care (not necessarily limited to the terminal phase) provided by health } \\
\text { professionals and informal caregivers (volunteers and family carers). They include } \\
\text { medical, psychological, and spiritual support, with the aim of helping people to } \\
\text { achieve peace, comfort, and dignity in their final days, weeks, and months (1). } \\
\text { "End-of-life care" or "care at end of life" refers to all aspects of the care relating to } \\
\text { dying, death, and bereavement that is provided toward the end of life. In this } \\
\text { context, "end of life" can be from the point of receiving a life-limiting diagnosis } \\
\text { through the months before death, up to and including the final hours-a continuum, } \\
\text { rather than a point in time. We use "end-of-life care" to refer to the care of people } \\
\text { with advanced life-limiting conditions, for whom death within one to two years is } \\
\text { likely, as well as those in the terminal phase of illness. It also encompasses care of } \\
\text { the bodily remains of the deceased person. }\end{array}$ \\
\hline Inclusion criteria & $\begin{array}{l}\text { The inclusion criteria were: } \\
\text { - content that contained MeSH search terms that included: a) any of the English- } \\
\text { speaking Caribbean countries and b) palliative and/or end-of-life care, terminal or } \\
\text { supportive care, terminal illness, medical futility, or hospice care } \\
\text { - } \quad \text { written in English } \\
\text { were accessible via the Internet and/or in peer-reviewed journals, and were original } \\
\text { papers, editorials, commentaries/ position papers, lectures, letters to the editor, or } \\
\text { regional reports. } \\
\text { content specifically addressed one or more of the populations of independent } \\
\text { English-speaking Caribbean nations (Antigua and Barbuda, the Bahamas, Barbados, } \\
\text { Belize, Dominica, Grenada, Guyana, Jamaica, Saint Lucia, Saint Kitts and Nevis, } \\
\text { Saint Vincent and the Grenadines, and Trinidad and Tobago) }\end{array}$ \\
\hline Exclusion criteria & $\begin{array}{l}\text { Articles that discussed palliation in a context other than end-of-life care, for example, the } \\
\text { use of palliation as a corrective measure for surgical procedures }\end{array}$ \\
\hline
\end{tabular}

Source: Prepared by the authors using study data.
Care"[MeSH]) OR "Terminally Ill" [MeSH]

OR "Medical Futility"[MeSH]) AND "Caribbean Region"[MeSH]). For the Web of Science, the Boolean search term "(palliative care OR terminal care OR terminal illness OR supportive care OR end-of-life care OR medical futility) AND Caribbean)" was used.

Additionally, we did a hand search of the references included in the selected publications and other relevant articles, such as policy reports. When a different database or information source was used, duplicate articles were removed by hand. No date restrictions on publications were used, but the search was conducted from June through

\section{Data analysis}

To obtain the relevant publications, three coauthors (NJ, KC, JC) reviewed the titles and abstracts, and applied the inclusion/exclusion criteria presented in Table 1.

To identify key issues surrounding palliative and end-of-life care in the November of 2015. 
English-speaking Caribbean, the Caribbean-based lead author (NJ) read completely and systematically categorized information obtained from the material included in the study. Two coauthors (KC and JC) additionally scanned the full texts of eligible articles to determine main themes and categories. Information was sifted, summarized, and later charted using a Microsoft Excel document developed for the process. For each publication, data were extracted on its title, main author's country, publishing journal, year published, research design, and focus country or region. Emerging key issues were discussed by all coauthors during team meetings. Critical input on the developing manuscript came from a Caribbean-based researcher (CCM).

The data extraction step of the review facilitates inductive identification of commonalities and themes $(16,18)$. Consequently, we grouped our information into five main recurring themes. As we considered a description of the situation across each of the themes, it became apparent that barriers are often mentioned in relation to the current state of palliative care development, so we also mapped reasons for barriers and possible ways to reduce them.

\section{RESULTS}

\section{Search}

MEDLINE yielded 59 article abstracts, with varying relevance to our aim (Figure 1). Of these, 18 were included in the study, plus an additional 7 after a hand search of the references included in the selected publications and supplemental online searches, for a total of 25 publications. The Web of Science database yielded 47 article abstracts, but none of them were new publications. The final 25 included articles from 1991 to 2015, and they had been published in 10 different journals (Table 2) (19-42). The first original studies, published in 2003, were from Grenada and Barbados. Other publications consisted of regional reports, commentaries/position papers, and editorials.

\section{Five main themes}

The review of the literature identified five themes: 1) culture and attitudes of health care providers, patients, and those

FIGURE 1. Flow chart of included articles $(N=25)$ used for the systematic scoping review of palliative and end-of-life care in the English-speaking Caribbean, 2015

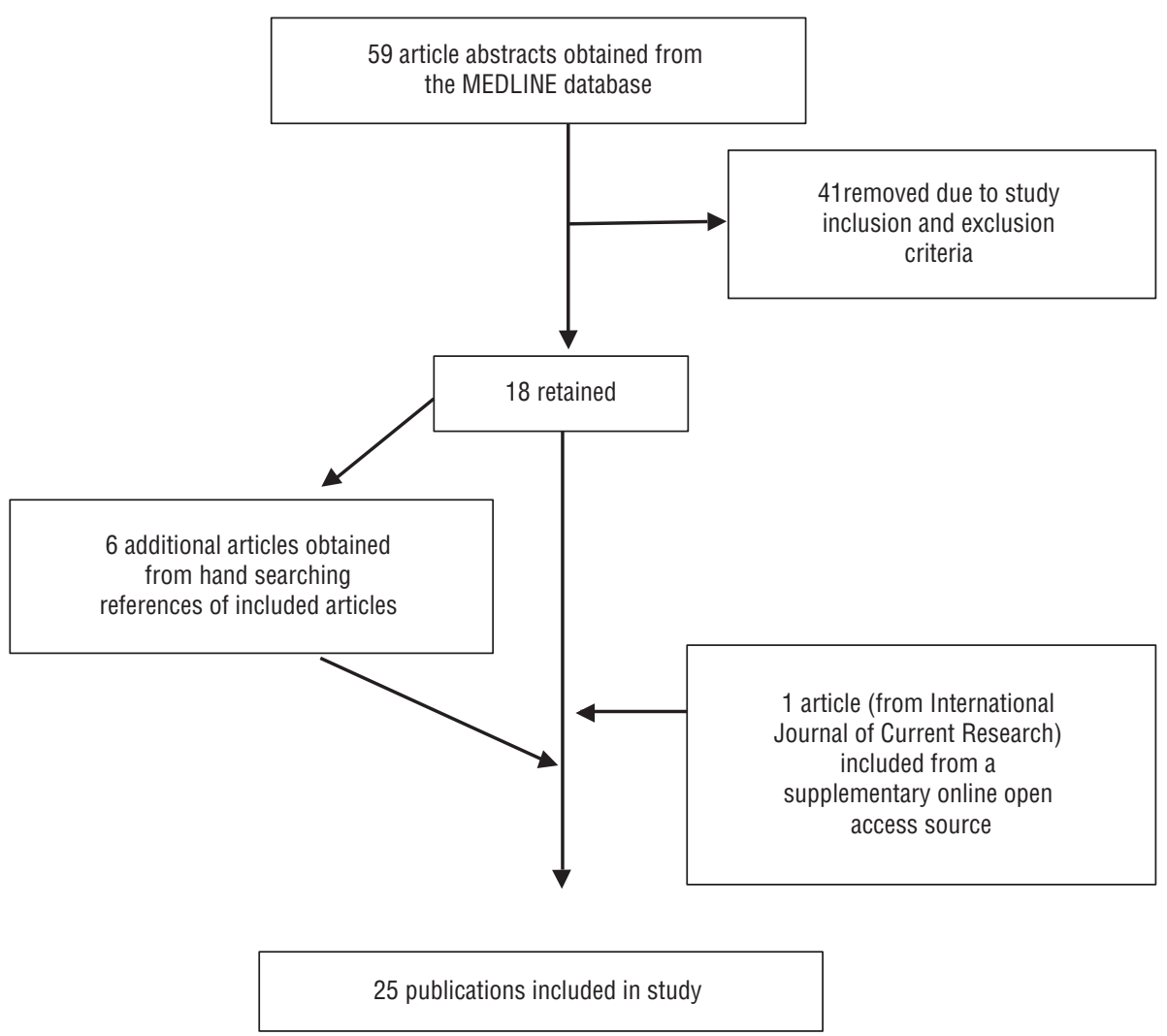

Source: Prepared by the authors using study data.

a We also conducted a search in the Web of Science database, which yielded 47 article abstracts, but none of them were new publications not already found in the MEDLINE search.

close to them towards illness death and dying; 2) access to and use of opioids for medical purposes; 3) development of services to complement palliative care capacity (education and training of health care professionals and care providers); 4) unmet palliative care needs (management of symptoms, financial burden, psychosocial burden borne by family caregivers, sickle cell anemia patients and other marginalized groups) and 5) palliative care research.

Across the themes, the review also identified barriers and suggested means of alleviating them. While themes, barriers, and solutions can overlap and are related culturally and socioeconomically, they are sufficiently distinct to be separated and examined. Due to limited data on palliative care in the English-speaking Caribbean, findings might relate to a specific country. However, the issues, circumstances, and challenges are likely to be similar in other countries of the region, due to their common history and shared cultural backgrounds.
An overview of the themes and corresponding issues is presented in online supplementary Table S1.

\section{Theme 1: Culture and attitudes of health care providers, patients, and those close to them towards terminal illness and death}

Historical ties to Europe and proximity to North America have encouraged the adoption of Western norms and values regarding lifestyles and taboos about death (21). The English-speaking Caribbean region's culture and attitudes are strongly shaped by religious beliefs that reinforce fatalistic attitudes and behaviors. For example, illnesses such as cancer are perceived as God-given punishment by some $(22,24)$, and pain is perceived by many as suffering that is unavoidable and unfortunate but part of God's overall plan. A historic norm is to expect and accept pain at the end of life (24-26). Mutual mistrust between health care practitioners and the public persists. Some members of the public believe that 
TABLE 2. Characteristics of publications $(N=25)$ used for the systematic scoping review of palliative and end-of-life care in the English-speaking Caribbean, 2015

\begin{tabular}{|c|c|c|}
\hline Characteristic & Category & No. of publications \\
\hline Year of publication & $\begin{array}{l}2011-2015 \\
2006-2010 \\
2001-2005 \\
1996-2000 \\
1991-1995\end{array}$ & $\begin{array}{l}8 \\
4 \\
8 \\
3 \\
2\end{array}$ \\
\hline Journal $(\mathrm{N}=25)$ & $\begin{array}{l}\text { Annals of Oncology } \\
\text { Cambridge Quarterly of Healthcare Ethics } \\
\text { Canadian Journal of Anesthesia = Journal Canadien D'anesthésie } \\
\text { Developing World Bioethics } \\
\text { Geriatric Nursing (New York, New York) } \\
\text { International Journal of Current Research } \\
\text { Journal of Pain And Symptom Management } \\
\text { Journal of Palliative Medicine } \\
\text { Public Library of Science Medicine } \\
\text { West Indian Medical Journal }\end{array}$ & $\begin{array}{l}3 \\
2 \\
1 \\
1 \\
2 \\
1 \\
2 \\
3 \\
1\end{array}$ \\
\hline $\begin{array}{l}\text { Original studies' }(n=10) \\
\text { type of publication }\end{array}$ & $\begin{array}{l}\text { Survey }(19,23,36,37) \\
\text { Bibliometric literature review (27) } \\
\text { Cross-sectional mixed methods (22) } \\
\text { Qualitative study/content analysis (24) } \\
\text { Prospective quantitative study (34) } \\
\text { Qualitative study/grounded theory (41) } \\
\text { Mapping exercise (20) }\end{array}$ & $\begin{array}{l}4 \\
1 \\
1 \\
1 \\
1 \\
1 \\
1\end{array}$ \\
\hline $\begin{array}{l}\text { Original studies }(n=10) \\
\text { country of origin }\end{array}$ & $\begin{array}{l}\text { Jamaica } \\
\text { Grenada } \\
\text { Barbados } \\
\text { Trinidad and Tobago } \\
\text { Other }\end{array}$ & $\begin{array}{l}1 \\
3 \\
1 \\
1 \\
4\end{array}$ \\
\hline $\begin{array}{l}\text { Original studies' }(n=10) \\
\text { population or topic of } \\
\text { interest }\end{array}$ & $\begin{array}{l}\text { Practicing clinicians working in the field of palliative care and/or cancer care }(19,37) \\
\text { Palliative care research }(27) \\
\text { Cancer patients, their caregivers, health care providers, key informants, and selected community members (22) } \\
\text { Caregivers of persons who died within a designated timeframe }(24) \\
\text { Patients admitted to a surgical intensive care unit who later died }(34) \\
\text { Health officials from } 13 \text { Caribbean Community and Common Market countries }(23) \\
\text { Members of the Sickle Cell Association of Grenada } \geq 18 \text { years old }(36) \\
\text { Registered nurses who worked at a Trinidadian private hospital's intensive care unit caring for paralyzed patients (41) } \\
\text { A global map and categorization of countries' overall state of palliative care practice and development (21) }\end{array}$ & $\begin{array}{l}2 \\
1 \\
1 \\
1 \\
1 \\
1 \\
1 \\
1 \\
1\end{array}$ \\
\hline
\end{tabular}

Source: Prepared by the authors using study data.

physicians are unwilling to be truthful when discussing negative diagnoses and terminal prognoses. The belief is that physicians avoid giving bad news, thinking that their patients will not be able to afford required medical treatments (22).

Reasons for these barriers. Options are either insufficient or lacking for patients and their families to obtain accurate and appropriate information about the trajectory of various cancers and terminal conditions, standards of medical care expected in wealthier nations, and psychosocial, financial, and educational support $(22,23)$. Poor communication between all parties hinders accurate information sharing regarding illness, death, and dying $(22,34)$. An absence of or unfamiliarity with institutional and health system policy impinges on knowledge, attitudes, and practices regarding the prescription of opioids for pain $(22,25)$.

Possible ways to reduce these barriers. To address the needs of patients and their caregivers, a revision of government policy, education, and communitybased care is recommended (22). Other suggestions include integrating palliative care into public health systems and improving analgesic availability and use $(22,24)$. Education campaigns can focus on policymakers and health care practitioners concerning pain management. Specifically, campaigns can target health care practitioners about improving their ability to communicate with patients, families, and caregivers (22, 24, 32). In addition, to dispel myths and misconceptions, the public can be educated about disease processes and available treatment options $(22,24)$. The development of broad-based multidisciplinary community-oriented palliative care programs is also necessary $(22,24,32)$.

\section{Theme 2: Access to and use of opioids for medical purposes}

The Global Opioid Policy Initiative reported in 2013 that consumption of opioids in most of the Caribbean is variable, with moderate levels of consumption by international standards (1-10 mg morphine equivalents/ 
capita/year) (19). The International Narcotics Control Board (INCB) regulates opiate importation for medical use, but Caribbean countries have not requested an importation increase due to low use (26). Limited hospital stocks of opioids contribute significantly to untreated medical pain $(24,25)$. Lynch et al. (20) recognized that in most regions of the world there is a strong association between development of palliative care and human development as measured by the U.N. Human Development Index (20); other publications support this view $(23,37)$.

Reasons for these barriers. One of the primary impediments to effective pain relief is the absence of written national policies. Such documents can improve awareness among health practitioners, policymakers, and the public on the safety and efficacy of opioids $(23-25,37)$. A less visible barrier is the reluctance of pharmaceutical companies and importers to invest in the registration and promotion of products such as oral immediaterelease morphine or oxycodone, which do not generate significant profit (19).

Possible ways to reduce these barriers. Health care professionals should follow the WHO's protocol for treating cancer pain (35), and the INCB suggests reforming restrictive government policy that hinders opiate availability $(19,37)$. Regulatory authorities should better cooperate and collaborate to increase accessibility of opioids for medical use $(26,37,38)$; medical educators should update their curricula to reflect new clinical and scientific evidence regarding the medical use of opioids to manage pain; and health officials and others should conduct periodic education campaigns to update health professionals (including pharmacists) about related developments in evidence-based practice $(19,23,25)$.

\section{Theme 3: Development of services to complement palliative care capacity}

Lynch et al. (20) mapped the global state of palliative care practice and development, placing countries into one of six categories. English-speaking Caribbean nations are in Groups 1, 2, and 3a. Group 1 (countries with no known hospice-palliative care activity) includes Antigua and Barbuda, Grenada, Saint Kitts and Nevis, and Saint Vincent and the Grenadines. Group 2 (countries with capacity-building activity) includes the Bahamas and Dominica. Group 3a (isolated palliative care provision) includes Barbados, Belize, Guyana, Jamaica, Saint Lucia, and Trinidad and Tobago. Belize and Saint Lucia moved from category 2 to $3 a$ between 2006 and 2011 (20).

Reasons for these barriers. As noted above, a nation's socioeconomic status and Human Development Index correspond with the extent to which it provides palliative care, with a lower socioeconomic status impeding palliative care development (22-26, 35, 36, 39-42). This is reflected in English-speaking Caribbean nations, where socioeconomics limit the resources and infrastructure needed for providing palliative or hospice care at the standards expected in wealthy nations (23).

Possible ways to reduce these barriers. The WHO suggests countries adopt a public health approach outlined in its 2002 National Cancer Control Guidelines: (i) an assessment of the magnitude of the problem; (ii) setting measurable objectives; (iii) evaluating possible strategies; and (iv) choosing priorities for initial activities (29). Other measures that may assist this process include governmentstakeholder consultations that draw attention to the unique settings and needs of each country (26) and advocacy from ministries of health and PAHO on allocating necessary resources to implement decentralized palliative care programs (43). Functions and resources of the private sector can be utilized to combat discrimination, prejudice, and ignorance about cancer, and to provide informal psychosocial and spiritual counselling, bereavement support, and fundraising initiatives to assist households (22).

\section{Theme 4: Unmet palliative care needs}

Outside the hospital setting, there are few if any systems or resources for ongoing palliative or hospice care in the English-speaking Caribbean. Few medical and nursing staff are trained in how to provide pain relief. In addition, disease registries and palliative care services capable of providing ongoing emotional, spiritual, financial, and social support or training for family caregivers do not exist in many health systems and jurisdictions $(22,29)$. Needs of specific populations, such as persons living with HIV/AIDS or sickle cell disease, are often overlooked, and few medical or other support services are available $(29,36)$.

Reasons for these barriers. Crosscutting and converging issues related to resources (e.g., inadequate transportation to medical appointments) and infrastructure, as well as dysfunctional hierarchical relationships among health practitioners, contribute to unmet needs (23). Where palliative care services do exist, patients and the public are generally unaware of what they offer and how to access them (24).

Possible ways to reduce these barriers. Programs involving a multidisciplinary team approach providing symptom management and psychosocial support for patients at home or in institutions can be developed and implemented (24). Examples likely to be effectively adapted to Caribbean socioeconomic and cultural contexts include effective pain relief (36) and sensitizing clinicians, administrators, and policymakers to the social services that patients and caregivers require (24).

\section{Theme 5: Palliative care research}

Investment in health research is limited in the Caribbean $(22,29,41)$. Historically, health research in English-speaking Caribbean nations is underfunded; research agendas and research groups are lacking; and experienced researchers may often work in isolation, without a collaborative network (27).

Reasons for these barriers. In developing countries, palliative care is not recognized as a discipline, and national strategies do not encourage related research or integrate new findings into health systems. Most palliative care and related research journals are based in developed countries and are only accessible through individual or institutional subscriptions that are prohibitively expensive in many low- and middleincome countries (27).

Possible ways to reduce these barriers. The capacity for health research could be improved through medical curricula and/or continuing education programs linked to the epidemiological and 
cultural contexts of the countries in the region. Strategies such as multidisciplinary palliative care research can stimulate collaboration among Caribbean researchers, and between researchers from developed and low- and middle-income countries. This process can facilitate a transfer of knowledge and may contribute to increased representation of Caribbean researchers on established editorial and research review boards (27).

\section{DISCUSSION}

This systematic scoping review identified five important themes among English-speaking Caribbean SIDS: 1) socioeconomic and cultural norms about terminal illness and death that influence the development and delivery of palliative and end-of-life care; 2) limited access to opioids for medical use; 3 ) limited palliative care services as compared to need; 4) unmet needs for palliative care; and 5) a lack of relevant research activity in the region.

This study is the first of its kind to comprehensively focus on and capture discussions in academic and grey literature surrounding palliative and end-of-life care specifically in the English-speaking Caribbean. A rigorous systematic process was used to extract core issues, and information was synthesized and presented as an overview in order to elucidate the specific contexts, challenges, and possible solutions.

Limitations of this review relate to the limited volume of published literatureparticularly original studies-on palliative and end-of-life care from or about the English-speaking Caribbean. There may be relevant articles besides the ones we found using our chosen search terms, databases, and hand searches. Likewise, the information we accessed may not capture all the relevant issues concerning palliative and end-of-life care in the region.

Findings from this study are not unique when compared to developing countries in Latin America or Africa. In those areas, the most common issues appear to be that palliative care is not considered a public health priority, and that there is a lack of empirical information on the provision of and access to palliative care. Nevertheless, specific reasons exist for the lack of palliative care development in the Caribbean. An earlier review (8) that appraised the quality of nine original studies from the Caribbean found that the peer-reviewed literature provided only limited information on the need for palliative care in Caribbean populations. The study concluded that there are specific needs for palliative care policy, staff training, education, access to analgesia, and palliative care support services.

Our broader exploration of the available literature corroborates these conclusions. Including nonresearch material helps to clarify the complexity of core issues. For example, poor communication between all parties hinders accurate information sharing, and cultural taboos and attitudes of the public toward terminal illness and death are strongly influenced by religious beliefs. Also, when Caribbean countries offer a minimal level of universal health care, that contributes to unmet palliative care needs.

For palliative care to be effective, one of the main requirements is that the care be broadly accessible for persons in need (44). Our study has identified challenges as well as opportunities for improvement in the English-speaking Caribbean for the overlapping issues of practice, policy, and research. The pertinence of these public health challenges is greatly magnified, given the region's context of aging societies faced with chronic and degenerative diseases.

\section{Practice}

Existing strengths and abilities may need to be further developed. For example, the Caribbean tradition of home care for the elderly (28) and the suggestion of having community-based care units (21) can be expanded by involving religious and other community groups working within their respective neighborhoods, and by training informal caregivers and community members in end-of-life caregiving. The Neighborhood Network in Palliative Care in the Indian state of Kerala may be an example that, with the appropriate adaptation to the specific context, could meet the needs for and improve access to palliative care of different communities in low-resourced countries (45). Training community lay people can supplement health care services and deepen the reach of and broaden the coverage of palliative care services. Access to care can be increased by bringing services to individuals who need them. Inspired by the WHO's concept of primary health care, the Kerala model appropriately addresses the challenge of increasing costs and commercialization of health care services in resource-poor regions.

\section{Policy}

Caribbean countries are faced with the absence of written national policiescombined with restrictive regulatory and legal procedures-on the medical use of opioid analgesics. Given this dilemma, Caribbean nations could be inspired by the example of how the country of Mongolia increased the medical use of opioids. In 2002, Mongolia was in its palliative care development infancy, with few analgesic drugs available (46). However, in less than five years, Mongolian stakeholders adopted and successfully implemented a strategy of using oncology services as a logical, humane, realistic, and cost-effective entry point for pain relief for a large percentage of those who needed palliative care (47). In addition, there is a vital need for an equity agenda if policies are to successfully reduce barriers for population health overall (48).

\section{Research}

Reliable studies to investigate the circumstances of dying and the needs for end-of-life care are a priority for developing palliative care in the Englishspeaking Caribbean. Pastrana et al. (7) noted that the clinical provision of care in low- and middle-income countries takes precedence over the development of palliative care research capacity. Further impeding research in resource-poor settings are such obstacles as limited institutional and regulatory frameworks, missing infrastructure, insufficient funding, and a shortage of qualified researchers. However, a viable strategy for establishing a research culture in English-speaking Caribbean countries might be integrating culturally relevant research methods into the existing curricula, while collaborating with foreign institutions capable of sharing their research expertise and infrastructure. Along with that, foreign benefactors could finance monitoring and evaluation activities (12). High-quality research is important and relevant because it can directly feed back into practice and policy 
by improving clinical skills training and by developing evidence-based health care interventions that are effective, feasible, and acceptable in resourcepoor contexts.

\section{Conclusions}

This study highlights the need for palliative and end-of-life care in a distinct group of developing nations in the English-speaking Caribbean. The sparse literature available makes it challenging to gauge the magnitude of the problem. However, many of the primary impediments to developing palliative care in the region are clear: inadequate policy, medication, service development, and access to services, combined with a lack of research on palliative and end-of-life care.

The similarities between the countries in the region can mean that progress on palliative care in one nation is used as a framework for intraregional development. Recognition of this by regional gatekeepers and policymakers may motivate them to invest in the necessary resources, structures, and initiatives that can propel the development of palliative and end-of-life care in the English-speaking Caribbean.

\section{REFERENCES}

1. Connor SR, Bermedo MC, eds. Global atlas of palliative care at the end of life. London: Worldwide Palliative Care Alliance; 2014. Available from: http://www.thewpca.org/resources/global-atlas-of-palliative-care/ Accessed on 1 July 2015.

2. World Health Organization. WHO definition of palliative care. Available from: http://www.who.int/cancer/palliative/ definition/en/ Accessed on 12 August 2015.

3. Pan American Health Organization. Health in the Americas, 2012 edition. Regional Outlook and Country Profiles [Report no. 636]. Washington, D.C.: PAHO; 2012. Available from: http://www.paho. org/salud-en-las-americas-2012/index. php?option $=$ com_content\&view $=$ article\&id=9\&Itemid=124\&lang=en Accessed on 3 August 2015.

4. Corr CA. Death in modern society. In: Doyle D, Hanks G, MacDonald N, eds. Oxford textbook of palliative medicine. $2^{\text {nd }}$ ed. Oxford: Oxford University Press; 1998:31-40.

5. Sepúlveda C, Marlin A, Yoshida T, Ullrich A. Palliative care: the World Health Organization's global perspective. J. Pain Symptom Manage. 2002;24(2):91-6.

6. Cohen J, Deliens L. Applying a public health perspective to end-of-life care. In: Cohen J, Deliens L, eds. A public health perspective on end of life care. Oxford: Oxford University Press; 2012:4-11.

7. Pastrana T, Vallath $\mathrm{N}$, Mastrojohn J, Namukwaya E, Kumar S, Radbruch L, et al. Disparities in the contribution of low- and middle-income countries to palliative care research. J. Pain Symptom Manage. 2010;39(1):54-68.

8. Maharaj S, Harding R. The needs, models of care, interventions and outcomes of palliative care in the Caribbean: a systematic review of the evidence. BMC Palliat Care. 2016;15:9. doi:10.1186/ s12904-016-0079-6.

9. Pham MT, Rajić A, Greig JD, Sargeant JM, Papadopoulos A, McEwen SA. A scoping review of scoping reviews: advancing the approach and enhancing the consistency.
Res Synth Methods. 2014;5(4):371-85. doi:10.1002/jrsm.1123.

10. The Commonwealth. Member countries. Available from: http://thecommonwealth.org/member-countries Accessed on 13 August 2015. bean Community. A community for all. Available from: http://www.caricom.org Accessed on 13 August 2015.

12. Grell GA. Health care system: chronic disease control in the English-speaking Caribbean, with special reference to hypertension. Trop Doct. 1986;16(4):181-4.

13. World Health Organization. Health cooperation in small island developing states. Available from: http://www.who.int/ country-cooperation / what-who-does / sids/en/ Accessed on 25 April 2016.

14. Caribbean Public Health Agency. About the Caribbean Public Health Agency (CARPHA). Available from: http://carpha.org/About Accessed on 11 January 2016.

15. Davis K, Drey N, Gould D. What are scoping studies? A review of the nursing literature. Int J Nurs Stud. 2009;46(10): 1386-1400.

16. Arksey H, O'Malley L. Scoping studies: towards a methodological framework. Int J Soc Res Methodol. 2005;8(1):19-32.

17. National Center for Biotechnology Information, U.S. National Library of Medicine. Medical Subject Headings. Available from: http://www.ncbi.nlm.nih.gov/mesh Assessed on 4 August 2015.

18. Armstrong R, Hall BJ, Doyle J, Waters E. Cochrane update: 'Scoping the scope' of a Cochrane review. J Public Health Med. 2011;33:147-50.

19. Cleary J, De Lima L, Eisenchlas J, Radbruch L, Torode J, Cherny NI. Formulary availability and regulatory barriers to accessibility of opioids for cancer pain in Latin America and the Caribbean: a report from the Global Opioid Policy Initiative (GOPI). Ann Oncol. 2013;24 (Supplement 11):xi41-50. doi:10.1093/annonc/mdt502.
11. Caribbean Community. CARICOM Carib-
Acknowledgments. The authors are grateful for the English editing done by Ms. Jane Ruthven, of Engedit.

Funding. Funded by the Research Council of the Vrije Universiteit Brussel: Strategic Research Programs (SRP 4).

Conflicts of interest. The authors have no competing interests.

Disclaimer. Authors hold sole responsibility for the views expressed in the manuscript, which may not necessarily reflect the opinion or policy of the RPSP/ PAJPH or PAHO.
20. Lynch T, Connor S, Clark D. Mapping levels of palliative care development: a global update. J Pain Symptom Manage. 2013;45(6):1094-6.

21. Branday JM. The dying patient - teaching doctors to care. West Indian Med J. 1996;45(2):45-7.

22. Spence D, Crath R, Hibbert A, PhillipsJackson K, Barillas A, Castagnier T, et al. Supporting cancer patients in Jamaica--a needs assessment survey. West Indian Med J. 2010;59(1):59-66.

23. Macpherson CC, Chiochankitmun N, Akpinar-Elci M. Hospice and palliation in the English-Speaking Caribbean. Camb Q Healthc Ethics. 2014;23:341-8. doi:10.1017/ S0963180113000959.

24. Kreitzschitz K, Macpherson CC. End of life care. Perspectives from families and caregivers. West Indian Med J. 2003;52(4): 311-6.

25. Macpherson CC, Aarons D. Overcoming barriers to pain relief in the Caribbean. Dev World Bioeth. 2009;9:99-104. doi: 10.1111/j.1471-8847.2009.00262.x.

26. Macpherson CC. Healthcare development requires stakeholder consultation: palliative care in the Caribbean. Camb Q Healthc Ethics. 2006;15(3):248-55.

27. Pastrana T, De Lima L, Eisenchlas J, Wenk R. Palliative care research in Latin America and the Caribbean: from the beginning to the Declaration of Venice and beyond. J Palliat Med. 2012;15(3):352-8. doi:10.1089/ jpm.2011.0429.

28. Golding J. Hospice home care. West Indian Med J. 1991;40(3):110-1.

29. Spence D, Merriman A, Binagwaho A. Palliative care in Africa and the Caribbean. PLoS Med. 2004;1(1):27-30. doi:10.1371/ journal.pmed.0010005.

30. Goldstein C, Anapolsky E, Park J, Immordino M, Ukoha N. Research guiding practice related to cultural issues at end of life care. Geriatr Nurs. 2004;25(1):58-9.

31. Dunkley MC. Comment on "Research guiding practice related to cultural issues at end of life care." Geriatr Nurs. 2004; 25(3):133. 
32. Rajé D. Palliative care. A rewarding specialty. West Indian Med J. 1996;45:41-2.

33. Rajé D. The Seventeenth Sir Harry Annamunthodo Memorial Lecture. West Indian Med J. 2006;55(1):62-7.

34. Hariharan S, Moseley HS, Kumar AY, Walrond ER, Jonnalagadda R. Futility-of-care decisions in the treatment of moribund intensive care patients in a developing country. Can J Anaesth. 2003;50(8):847-52.

35. Spence D. Palliative care: end of life care. West Indian Med J. 2003;52(4):265-6.

36. Shah PD, Macpherson CC, Akpinar-Elci M. Impact of undertreated sickle cell pain in the Caribbean. West Indian Med J. 2014;1(2):63-6. doi:10.7727/wimjopen.2014.145.

37. Cherny NI, Cleary J, Scholten W, Rabdruch L, Torode J. The Global Opioid Policy Initiative (GOPI) project to evaluate the availability and accessibility of opioids for the management of cancer pain in Africa, Asia, Latin America and the Caribbean, and the Middle East: introduction and methodology. Ann Oncol. 2013; 24(Supplement 11):xi7-xi13.

38. De Lima L. Advances in palliative care in Latin America and the Caribbean: ongoing projects of the Pan American Health
Organization (PAHO). J Palliat Med. 2001;4(2):228-31.

39. Cleary J, Radbruch L, Torode J, Cherny NI. Next steps in access and availability of opioids for the treatment of cancer pain: reaching the tipping point? Ann Oncol. 2013;24(Supplemental 11):xi60-xi64.

40. Barnard D. World Health Organization guidelines for national narcotics control policies. J Palliat Med. 2002;5(4): 575-7.

41. Onuoha P, Samaroo S. Palliative care to paralysed patients: lived experiences of registered nurses at the intensive care unit of a major care centre in a Caribbean island. Int J Curr Res. 2015;7(1):11670-8.

42. Hanna WJ. Ethical issues and intensive care: a look to the 90s. West Indian Med J. 1991;40(4):153-4.

43. De Lima L, Bruera E. The Pan American Health Organization: its structure and role in the development of a palliative care program for Latin America and the Caribbean. J Pain Symptom Manage. 2000;20(6): 440-8.

44. Clemens KE, Kumar S, Bruera E, Klaschik E, Jaspers B, De Lima L. Palliative care in developing countries: what are the important issues? Palliat Med. 2007;21:173-5.
45. Kumar SK. Kerala, India: a regional community-based palliative care model. J Pain Symptom Manage. 2007;33(5):623-7.

46. Davaasuren O. Mongolia: the present situation and future of palliative care. J Pain Symptom Manage. 2002;24(2):208-10.

47. Davaasuren O, Stjernswärd J, Callaway M, Tsetsegdary G, Hagan R, Govind S, et al. Mongolia: establishing a national palliative care program. J Pain Symptom Manage. 2007;33(5):568-72. doi:10.1016/j. jpainsymman.2007.02.017.

48. Kickbusch I, Buckett K, eds. Implementing Health in All Policies: Adelaide 2010. Adelaide: Department of Health, Government of South Australia; 2010. Available from: http://www.who.int/sdhconference/resources/implementinghiapadel-sahealth-100622.pdf Accessed on 24 July 2017.

Manuscript received on 28 October 2016. Revised version accepted for publication on 9 August 2017

Objetivos. Establecer los temas comunes documentados en la bibliografía sobre los cuidados paliativos y al final de la vida en los pequeños estados insulares en desarrollo del Caribe de habla inglesa, y describir los obstáculos, las estrategias de mejora y los pasos futuros que se sugieren.

Principales temas, obstáculos y soluciones en relación con los cuidados paliativos y al final de la vida en el Caribe de habla inglesa: examen sistemático exploratorio Métodos. En el 2015, realizamos un examen sistemático exploratorio de la bibliografía pertinente encontrada por medio de MEDLINE y las bases de datos de Web of Science. Complementamos el examen con búsquedas de otras fuentes electrónicas e impresas para esquematizar los conceptos fundamentales y resumir los temas.

Resultados. Los datos primarios y otra bibliografía sobre las naciones del Caribe de habla inglesa o provenientes de ellas son relativamente escasos. La bibliografía disponible ofrece un panorama de la situación existente en la región y explora las razones por las que los cuidados paliativos y al final de la vida son limitados en estas naciones. La presente revisión detectó obstáculos en cinco áreas principales, recurrentes en toda la bibliografía: $a$ ) factores culturales y actitud de los prestadores de atención de salud, los pacientes y las personas cercanas a ellos hacia la enfermedad terminal y la muerte; b) disponibilidad y uso de opioides ; c) desarrollo limitado de los servicios de cuidados paliativos; $d$ ) necesidades de cuidados paliativos no atendidas, y e) investigación limitada sobre los cuidados paliativos o al final de la vida.

Conclusiones. Nuestro análisis ayuda a documentar la necesidad de cuidados paliativos y al final de la vida en los pequeños estados insulares en desarrollo del Caribe de habla inglesa, y pone de relieve sugerencias para avanzar en la práctica, la política y la investigación relacionadas.

Palabras clave Cuidados paliativos; cuidado terminal; Indias Occidentales Región del Caribe. 
RESUMO

Temas principais, barreiras e soluções aos cuidados paliativos e de pacientes terminais em países de língua inglesa do Caribe: uma scoping review
Objetivos. Identificar temas comuns documentados na literatura científica sobre cuidados paliativos e de pacientes terminais nos pequenos Estados insulares em desenvolvimento do Caribe e descrever barreiras, estratégias de melhoria e rumos a serem tomados.

Métodos. Em 2015, foi realizada uma revisão sistemática do tipo scoping review da literatura científica relevante identificada nas bases de dados MEDLINE e Web of Science. Para complementar, foram feitas buscas em outras fontes eletrônicas e impressas para mapear os conceitos básicos e resumir os temas.

Resultados. Os dados primários e outros dados da literatura provenientes e acerca dos países de língua inglesa do Caribe são relativamente escassos. A literatura disponível oferece um panorama geral da situação da região e examina por que os cuidados paliativos e dos pacientes terminais são limitados. A revisão permitiu identificar barreiras em cinco áreas principais recorrentes nos estudos: i) cultura e atitudes dos profissionais da saúde, dos pacientes e das pessoas próximas que acompanham o paciente com doença terminal e morte; ii) disponibilidade e uso de opioides; iii) progresso restrito dos serviços de cuidados paliativos; iv) necessidades da atenção paliativa não atendidas e v) pesquisas pouco extensas sobre cuidados paliativos e dos pacientes terminais.

Conclusões. Nossa análise contribui para documentar a necessidade de cuidados paliativos e dos pacientes terminais nos pequenos Estados insulares em desenvolvimento do Caribe e sugere o rumo a ser tomado com relação a práticas, políticas e pesquisas.

Cuidados paliativos; assistência terminal; Índias Ocidentais; Região do Caribe. 